\title{
Aboutness Topics in Old and Middle French: A corpus-based study on the fate of $V 2$
}

\author{
AROLDO DE ANDRADE \\ Federal University of Minas Gerais \\ aroldo.andrade@gmail.com
}

\begin{abstract}
This article investigates the loss of aboutness topics in preverbal position in the history of French, using a corpus-based research on preverbal accusative objects. A comparison of Old and Middle French with Modern French reveals that new-information focalization had disappeared by the $14^{\text {th }}$ century, whereas aboutness topicalization had in turn vanished by the end of the $16^{\text {th }}$ century, along with other marked constructions. Combined with the generative premise that independent pragmatic factors should not trigger syntactic change, the results of this study suggest the reanalysis of the grammar as V-to-I in Renaissance French is responsible for blocking the derivation of aboutness topicalization. An alternative proposal based on phase extension and on Relativized Minimality, in a version affecting some types of $\mathrm{A}^{\prime}$-movement, relates those two diachronic shifts. The article concludes with the idea that the study of marked constructions may be recast as offering diagnostics on broader syntactic changes.
\end{abstract}

Keywords: Aboutness topics, Information Structure, Old French, Phase Theory, Word Order

\section{Résumé}

Cet article examine la perte des topiques d'à-propos (aboutness topics) en position préverbale dans l'histoire du français, à partir d'un corpus de compléments accusatifs préverbaux. Une comparaison des données de l'ancien et du moyen français avec ceux du français moderne révèle que la focalisation informative avait disparu au $14^{\mathrm{e}}$ siècle, alors que la topicalisation d'à-propos ne disparaît qu'à la fin du $16^{\mathrm{e}}$ siècle, en même temps que d'autres constructions marquées. Combinés à la prémisse générative selon laquelle des facteurs pragmatiques indépendants ne devraient pas déclencher de changement syntaxique, les résultats de cette étude suggèrent que la réanalyse du mouvement V-à-I, dans la grammaire du français de la Renaissance, est responsable de la perte de la topicalisation d'à-propos. Une proposition alternative basée sur l'extension de phase et une version de la contrainte de minimalité relativisée

I thank the editors of this issue, and two anonymous reviewers for their constructive comments, as well as an anonymous proofreader for detailed corrections. I also acknowledge the financial support of Fapesp (individual project No. 2013/24637-8, and thematic project 2012/06078-9, led by Charlotte Galves), and academic support in Montreal from Marie Labelle and Paul Hirschbühler. Any remaining inconsistencies are my own. 
visant certains types de mouvement $\mathrm{A}^{\prime}$ relie ces deux changements diachroniques. Ceci permet de supposer que l'étude des constructions marquées peut acquérir un nouveau rôle, et offrir ainsi des diagnostics sur des changements syntaxiques plus larges.

Mots-clés: Topiques d'à-propos, structure informationnelle, ancien français, théorie des phases, ordre des mots

\section{INTRODUCTION}

A long-standing tradition of research in Old French has sought to unveil the relation between information structure and syntax and the verb-second (V2) hypothesis (Thurneysen 1892, Priestley 1955, Rickard 1962, Skårup 1975, Marchello-Nizia 1995, Labelle \& Hirschbühler 2005, among others). ${ }^{1}$ This article builds on this practice by offering a corpus-based investigation of the nature of left-peripheral elements from the $11^{\text {th }}$ to the $16^{\text {th }}$ century. The data, properly referenced further below, were collected from the following corpora: MCVF (Modéliser le Changement: les Voies du Français), the Penn Supplement, and the BFM (Base de Français Médiéval). The use of automatic queries helped to build a bigger database than was found in most previous works on the same subject.

Among the left-peripheral elements identified, this study focuses on aboutness topics, that is, elements stored in the common ground, which the sentence develops. Due to the V2 character of Old French, aboutness topics trigger subject-verb inversion as illustrated in $(1):^{2}$

(1) Aboutness topicalization

car cest abit $t_{i}$ me lessa mon pere et ma mere $t_{i}$

for this clothing me left.3sG my father and my mother

'For my father and my mother left this clothing to me'

(de Joinville, Histoire de Saint Louis, p.17)

Aboutness topicalization shows the connection of the left-peripheral topic to a gap inside the clause. However, Old French aboutness topics also appear in a different construction - left dislocation - where the topic is resumed by a clitic, a pronoun or even an epithet, as (2) illustrates.

\footnotetext{
${ }^{1}$ The following abbreviations are used: AB: Aboutness topic; ACC: accusative; ACC-INF: accessible-inferred; ACC-GEN : accessible-generic; ACC-SIT: accessible-situational; ADV: adverb; BFM: Base de français médiéval (corpus); CF: Contrastive focus; ConD: conditional; CT: Contrastive topic; DAT: dative; EPP: Extended Projection Principle; FM: Familiar topic; FS: Frame-setting topic; FUT: future; GEN: genitive; INF: inferred; LOC: locative; MCVF: Modéliser le changement: les Voies du français (corpus); NEG: negative; NF: New-information focus; NOM: nominative; NONREF: non-referential; NONSPEC: non-specific; OSV object-subject-verb order; OV: pre-verbal object; OXV: object-adjunct-verb order; SOV: subject-object-verb order; PL: plural; PST: past; PTCP: participle; QUANT: quantified noun; SG: singular; SOV: subjectobject-verb order; V-to-C: verb to complementizer movement; V-to-I (V-à-I): verb to Infl movement; V2: verb second; VO: post-verbal object; X: adjunct; XOV: adjunct-object-verb order.

${ }^{2}$ The literary works cited can be found in the Sources list and are identified with chapter (ch.), line (l.), page (p.), sentence (s.), and/or stanza (st.).
} 
(2) LeFT DisLocation

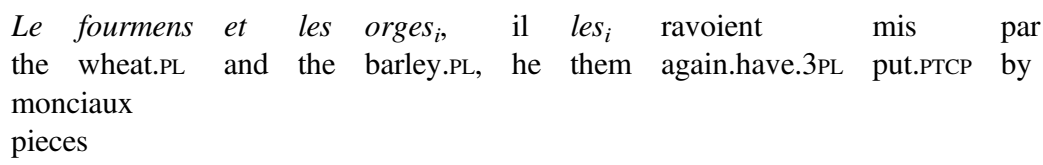

'He had put again the wheat and the barley by parts'

(de Joinville, Histoire de Saint Louis, p.63)

The main issue examined in this article is the disappearance of aboutness topicalization in Modern French, which seems to follow a general Romance trend (Poletto 2006, Mensching 2012), although it does not occur in Portuguese (de Andrade 2015).

Previous literature has provided three predominant hypotheses to explain this loss. The oldest, first formulated by Foulet (1919) and von Wartburg (1946), proposes that it is caused by the ambiguity resulting from the loss of the morphological case. However, as argued by Adams (1987), this idea is not tenable because some languages lacking overt case marking, such as Dutch, still have aboutness topics and V2. Therefore, the following more recent hypotheses should instead be considered.

Hypothesis A: Loss of aboutness topicalization is an independent process, possibly related to changes in pragmatic and prosodic shifts that eventually led to the loss of V2. In other words, there has been a frequency shift in the number of OSV clauses, $\mathrm{S}$ being in most cases a pronoun. This type of structure was ambiguous between two structures, V-to-C and V-to-I, between which the latter finally won with the fixation of pronouns as clitics (Adams 1987).

Hypothesis B: Aboutness topicalisation in French was, and continues to be, a pure form of left dislocation, disguised by the fact that the resumptive, as a weak pronoun, could instead be realized as a null pronoun. This proposal relies on the assumption that the choice between overt and null pronouns is free (Troberg, 2004).

The remainder of the article is organized as follows. Section 2 discusses the use of marked topic constructions in Modern French so as to distinguish this grammar from the ones of Old and Middle French. Section 3 presents the methodology and the qualitative and quantitative results from the corpus-based study, which helped to assess the hypotheses presented above. Section 4 examines these findings, linking the disappearance of aboutness topicalization with the fate of V2. Section 5 provides some conclusions and directions for further research.

\section{MARKED TOPIC CONSTRUCTIONS IN MODERN FRENCH}

First of all, in order to determine the type of data to be tracked in the Old and Middle French corpora, it is necessary to observe the distribution of marked topic constructions in Modern French.

The most common constructions used to convey marked topics in Modern French are left dislocation and right dislocation, where a resumptive element, such as a clitic or a possessive pronoun, is coreferential to the peripheral topic, as shown in (3) from de Cat (2007: 98, 99). 
(3) a. Les malotrus $_{i}$, on ne les $i$ invite pas. the louts one NEG them invite not

b. On ne les invite pas, les malotrus $_{i}$. one NEG them invite not the louts 'We don't invite louts.'

With a focus on left-hand topics, de Cat (2007) observes that the well-established distinction between clitic left dislocation and hanging topic left dislocation is not clear in Modern French. These two constructions are distinguished based on the presence of agreement in case, gender, and number between the resumptive and the topic; a phenomenon also dubbed as connectivity (Cinque 1990). For this reason and for simplicity, I use the basic term left dislocation, although I consider the construction to be closer to a "hanging topic left dislocation". In related work, in addition to left dislocation, there is frame-setting topicalization, where the peripheral constituent is a discourse topic that bears a loose relation to the clause, as depicted in the following example from Blasco $(1997: 11):^{3}$

(4) Les lycées techniques... tu arrives avec un bac de technicien. the high.schools technical.PL... you arrive with a diploma of technician 'Technical high schools, you arrive with a technician diploma.'

The constituent in italics in (4) fits the definition of frame-setter in Krifka (2007: 46), as an element that frames "the set in which the following expression should be interpreted."

The example in (5), taken from de Cat (2007: 174), represents another kind of marked construction, which conveys a contrast between the topic and other members of a set.

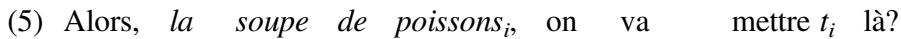
then, the soup of fish.PL, one go.3sG put there 'And then the fish soup, shall we put it there?'

The sentence in (5) describes a scene where a set of dishes is being arranged, and the soup must be assigned a specific place. I call this construction contrastive topicalization because it encodes a topic and a contrastive focus at the same time (see ErteschikShir 1997 and Krifka 2007 for analyses combining topic and focus in different layers).

The previous classification raises a question about the necessity of resumption in left dislocation: is it mandatory, or are there contexts where it is optional? Barnes (1985) has pointed out that what seems to be topicalization should, in fact, be treated as a special case of left dislocation with zero anaphora in generic contexts where ça would be an appropriate resumptive pronoun, as in (6), adapted from de Cat (2007: 85).

${ }^{3}$ The term frame-setting is used because it replicates the classification adopted in the analysis of Old and Middle French data presented further below. 
(6) Les gâteaux $i$, j'adore $\left(c ̧ a_{i}\right)$.

the.PL cakes $\mathrm{I}=$ adore (this)

'I love cakes.'

As a matter of fact, the same pattern has been observed by Casielles-Suárez (2004) for Spanish, where non-resumption is attributed to the clitics' inability to refer to generic NPs. Other non-resumption contexts are found in the literature. De Cat (2007) presents those related to object omission. Likewise, Rizzi (1997) notes that indirect objects and locatives are not obligatorily resumed in Italian and French, as seen below (Rizzi 1997: 322):

(7) $\mathrm{Au}$ Pape $_{i}$, personne n'oserait (lui $i_{i}$ parler ainsi. to.the Pope, nobody NEG=would.dare.3sG (him) speak like.this 'Nobody would dare to talk to the Pope like this.'

The optional nature of left dislocation is analyzed in Frascarelli (2000) as a subcase of pro-licensing (Rizzi 1986) while assuming, as many authors have since Hirschbühler (1975), that the left-dislocated topic is base-generated in the left-periphery and coindexed to a constituent inside the clause. As illustrated in (7), there is a preposition that licenses the NP topic via inherent case, which is lacking in direct objects. These provisos, however, fail to explain some cases of non-resumption, such as the one in (5).

This summary indicates that topicalization is not used in Modern French to convey an aboutness topic, that is to say, an element that only retrieves old information, without a contrastive meaning. This sort of topic, illustrated in (1), is expected to appear instead in the left dislocation construction, even though the resumptive is sometimes covert for independent reasons. This paves the way for the diachronic analysis in Section 3, where it is shown that preverbal aboutness topics represent a distinguishing factor between Modern French and its earlier stages.

\section{The DisTRIBUtion OF ABOUTNESS TOPICS IN OLD AND MidDle FrenCH}

This section presents the methodology and the results obtained from the corpus-based research.

\subsection{The data}

The dataset used for this research consists of 665 root clauses from Old and Middle French, as well as from the beginning of Renaissance French, where nominal objects were found in a preverbal position.

Fifteen texts, ranging from the $11^{\text {th }}$ to the $16^{\text {th }}$ century, were used. Some texts are from the MCVF corpus (Martineau et al. 2007 and Martineau et al. 2010; see also the detailed bibliography in Martineau 2008), others from the Penn Supplement corpus (Santorini and Kroch 2014), and the remainder from the BFM corpus (Guillot 2014). For more details on the sampling procedure, see Appendix A.

CorpusSearch was used to extract data from the parsed texts with the help of two queries, presented in Appendix B. For the non-annotated texts, all sentences were manually counted, and tokens were included in the dataset according to the sampling 
criteria. Overall, the sampling procedure involved the choice of texts, whose length ranged from 6,000 to 9,000 sentences, from which the data were retrieved. This criterion excludes texts from the $11^{\text {th }}$ century, as none were sufficiently long. For the $11^{\text {th }}$ and $12^{\text {th }}$ centuries, most of the data came from poetry texts, which may have biased the results. Nevertheless, a comparison between these data and those from the texts written in the $13^{\text {th }}$ century onwards showed that they are a worthy contribution. $^{4}$

Preverbal objects were classified according to the informational roles listed in Table 1, based on the annotation scheme proposed in Petrova and Solf (2009). ${ }^{5}$

As Petrova and Solf (2009) explain, new-information focus ( $\mathrm{NF}$ ) and contrastive focus (CF) may apply within the same focus domain. While a contrastively focussed constituent is in a contrastive relation with another constituent in the discourse, new information focus contributes information that is either requested by a preceding $w h$ question or necessary to develop the discourse. The authors emphasize that no direct connection exists between newness, a type of information status, and new-information focus.

Although Petrova and Solf (2009) do not clearly distinguish topics, Götze et al. (2007) propose a clear-cut contrast between aboutness topics (AB) and frame-setting topics (FS), which I have adopted. Götze et al. define aboutness topics as entities "about which the sentence under discussion makes a predication" (p. 163) and frame-setting topics as "the frame within which the main predication of the respective sentence has to be interpreted" (p. 167). Petrova and Solf (2009) provide rules to identify aboutness topics based on definiteness and information status, the second of these being discussed below. To these rules, they add that the analyst must also consider aboutness and syntactic realization in the clause. Aboutness is that the sentence is about $\mathrm{X}$, where $\mathrm{X}$ is the topic constituent, whereas syntactic realization in the clause is the identification of a marked topic construction by the use of specific features.

Because our focus here is preverbal accusative objects, no cases of frame-setting topics have been included. In addition, I distinguish contrastive topics (CTs), which I consider as constituents bearing both an aboutness topic tag and a contrastive focus tag.

(8) [L'armee dudit duc estoit en deux parties.] the $=$ army of.the.said duke was in two sections L'une menoit le mareschal de Bourgongne... the $=$ one lead.PST.3sg the marshal of Burgundy 'The aforesaid duke's army was (split) into two sections; the marshall of Burgundy led one (of them)...'

(de Commynes, Mémoires, p.146)

The constituent l'une [partie] in (8) could receive an AB tag because it refers to the previous referent deux parties [de l'armée]. Nevertheless, it must be classified as a

\footnotetext{
${ }^{4}$ A portion of the Psautier d'Oxford was included in the $12^{\text {th }}$ century dataset. This is a prose text whose edition is considered more trustworthy than that of Les quatre livres des rois. I thank an anonymous reviewer for this suggestion.

${ }^{5}$ This annotation is also roughly adopted in Zaring (2010) and Steiner (2014).
} 


\begin{tabular}{lll}
\hline \hline Basic role & Tag & Description \\
\hline Focus & NF & New-information focus \\
& CF & Contrastive focus \\
Topic & AB & Aboutness topic \\
& FS & Frame-setting topic \\
\hline \hline
\end{tabular}

Table 1: Annotation scheme of informational role

Ст because it also implies a choice for one of the alternatives previously set, that is, the two parts of the duke's army; and this is a particular feature of CF. There are therefore four informational roles coded in this study: new-information focus (NF), contrastive focus (CF), aboutness topic (AB), and contrastive topic (CT). ${ }^{6}$

From this perspective, informational status was also used to support the classification of informational roles. The annotation scheme adopted is the tagset described in Haug et al. (2014: 33), given in Table 2. ${ }^{7}$

This annotation scheme was chosen because it was shown to be one of the most efficient for encoding givenness, according to multiple tests on the use of verb-object order in Old English carried out in Taylor and Pintzuk (2014). The scheme includes a matrix of tags, categorized according to specificity and reference contexts, in addition to KIND and QUANT, which are considered as special.

Specific tags are used for referents available for anaphoric pickup; they occur in the main narrative storyline. Nonspecific tags occur in short-term contexts set up by the narrator for specific purposes, such as relating hypothetical, negated, desired, or possible scenarios. For this reason, they are unavailable for anaphoric uptake in the main storyline but may be inside the same short-term universe. Examples for the specific tags are provided below.

Reference contexts indicate that givenness is understood as an addressee-based notion. If the referent is found in the discourse context that precedes a certain utterance, as in (9), it receives the tag OLD.

(9) Cest mien seignur en bataille faillirent this my lord in battle abandoned.3PL

'They abandoned this lord of mine in (the) battle.' (La chanson de Roland, p.195)

The nonspecific counterpart of OLD (NONSPEC-OLD) occurs in opaque contexts, such as in the scope of negation when it is coreferent to a previous element such as QUANT (see (15) for this tag). If the referent is found in a scenario context, that is, one that includes knowledge such as 'buses have drivers', it receives the tag ACC-INF, which means accessible-inferred. It is shown in (10), where the trigger for the inference 'items in a meal', pain ('bread'), is shown in boldface. Its counterpart in opaque contexts is NONSPEC-INF.

\footnotetext{
${ }^{6}$ No distinction was made between constituents encoding new information alone, or as part of a bigger constituent or the whole sentence, although it is possible to do so in some cases.

${ }^{7}$ The tagset was originally developed for the Project Pragmatic Resources in Old IndoEuropean languages (PROIEL).
} 


\begin{tabular}{lll}
\hline \hline Context & Specific tag & Non-specific tag \\
\hline Discourse & OLD & NONSPEC-OLD \\
Scenario & ACC-INF & NONSPEC-INF \\
Encyclopaedic & ACC-GEN & - \\
Situation & ACC-SIT & - \\
- & NEW & NONSPEC \\
& KIND & - \\
& - & QUANT \\
\hline \hline
\end{tabular}

Source: Haug, Eckhoff, and Welo (2014:33)

Table 2: Annotation scheme of informational status

$\begin{array}{lllll}\text { (10) } & \text { fu l'os si povre qu'il n'i } & \text { avoit } \\ \text { then was the }=\text { army so poor that }=\text { it NEG }=\text { LOC } & \text { had.3sG } \\ \text { mie pain a paistre plus de chent } & \text { hommes, } \\ \text { at.all bread to feed more of a.hundred } & \text { men, } \\ \text { mais char } e \text { vin avoient il assés. } & \\ \text { but meat and wine have.PST.3P they enough } & \end{array}$

'Then the army was so poor that there was no bread to feed more than a hundred men, although they had enough meat and wine.'

(de Clari, La conquête de Constantinople, p.102)

Furthermore, the encyclopedic context includes knowledge shared between author and recipient at the time when the text was written, as shown in (11). There is no nonspecific counterpart for this context, nor is there for the situation context, which refers to the joint surroundings of the speaker and hearer, illustrated in (12).

(11) Deu servirei, le rei ki tot guvernet God serve.Fut.1SG the.ACC king that all rules

'I will serve God, the king that governs all.'

(de Joinville, Histoire de Saint Louis, p.231)

(12) Le blanc osberc li ad descust el cors the.ACC white hauberk him has unravel.PTCP on.the body 'He [=Marganice] has unpicked the white hauberk over his [=Olivier's] body'

(La chanson de Roland, st.145)

If the referent cannot be found in any context, the constituent is tagged as NEW if encountered in the main storyline, as in (13). On the occasion that the element occurs within a short-term context, it is tagged as NONSPEC.

(13) Glaive fortraistrent li pecheur sword drew.3PL the.NOM sinners

'The sinners drew (the) sword.' (Psautier d'Oxford, ch.36, 1.14)

Finally, two special tags are used for generic and quantified NPs: KIND and QUANT. The former does not refer to individuals as other specific NPs do, as shown in (14). The latter may be non-referential or include reference to a plural discourse representation, as in (15). 
(14) Viandes envia à els en abundance meat.PL sent.3SG to them in abundance 'He has sent them meat in abundance.'

(Psautier d'Oxford, ch.77, 1.29)

(15) Pluisseurs paroles disoit on de li en France et a Paris. many words said.3sg one of him in France and in Paris 'People said many words about him in France and in Paris.'

(Froissart, Chroniques, p.483)

The classification above helps to identify non-referential constituents, which cannot be topics. The identification of nonspecific referents is also valuable because they are less likely to act as topics. The previously described methodology thus provides a safer way to identify informational roles than the correspondence rules in Marchello-Nizia (1995), which are uniquely based on the form of the NP. However, there is a special category in that analysis that consists of objects included in light-verb constructions, especially common in the older periods of French. These objects were counted as NONREF because they do not have a referent, and do not fit any of the mentioned categories. Following Marchello-Nizia's observations, these objects were coded in the present study as new-information focus.

\subsection{Qualitative results}

Before a more extensive presentation of the results, I turn first to a systematic study of preverbal objects in the Middle French text of de Commynes (1964 [1498]), to test the predictions made by hypothesis B. This is a crucial step; if topicalization in Old and Middle French is indeed left dislocation in disguise, it would critically affect the presentation of the quantitative results, not to mention the very direction of the analysis.

Hypothesis B rests on two arguments: (i) the resumptive in the purported left dislocation is freely null, which means that overt resumptives are not favored in any structural environments; (ii) only null pronouns, not null variables, can be used in argumental positions. An examination of both arguments follows.

As for structural environments, embedded contexts have been shown to interact with only some types of marked constructions (Bianchi and Frascarelli 2010). For instance, topicalization is accepted only in root clauses and embedded clauses with root properties in English (Haegeman 2012 and references therein). In contrast, (16) and (17) suggest that both aboutness topicalization and left dislocation were possible in embedded clauses of Old French:

(16) je sai [que vous la derrenier aumosne me donrez $t_{i}$ ]. I know that you the last charity to.me give.Fut.2PL 'I know that you will give me the last charity' (Roman de Cassidorus, p.215)

(17) Gardez [que ces lettres que vous receüstes

beware that these letters that you received.2SG

par Melsius $_{i}$ que il les le $_{i}$ vous envoiast].

from Melsius that he them to.you sent. $3 \mathrm{sG}$

'Watch if it is indeed the case that it was Melsius who sent the letters that you have received from him.' 
(Lit.: 'Pay attention that, these letters that you received from Melsius, that he indeed sent them to you.')

(Roman de Cassidorus, p.330)

The structure in (16) has a different distribution from Modern French. Notice that, if this construction were contrastive topicalization, it should not fit this sort of embedded context, as is the case in English. Moreover, the example in (17) shows that left dislocation is also available in embedded clauses. Therefore, syntactic contexts do not help to distinguish the two constructions in a synchronic analysis of the Middle French data, although it is diachronically different from Modern French.

Pragmatic contexts can also be taken into account to distinguish different uses of topicalization, as highlighted in (18) and (19).

(18) [le secours qui vint de Bourgongne, que mena

the help that came from Burgundy, that led.3sG

le seigneur de Coulches, le marquis de Rothelin,

the lord of Couches, the marquis of Rothelin,

le seigneur de Montagu et autres] [...]

the lord of Montaigu and others

Ceste assemblee avoient faicte en Bourgongne

this assembly have.PST.3PL do.PTCP in Burgundy

le conte de Beaujeu et le cardinal de Dourbon...

the count of Beaujeu and thecardinal of Dourbon

'[...the help that came from Burgundy, which was led by the lord of Couches, the marquis of Rothelin, the lord of Montaigu and others] [...] Le count of Beaujeu and the cardinal of Dourbon had gathered this meeting.' (de Commynes, Mémoires, p.18)

(19) [Des gens de cheval qui estoient avec ledict duc of.the people of horse that were.3PL with the.said duke

de Bourgogne, il en $y$ envoya une partie

of Burgundy, he GEN LOC sent.3sG a portion

pour donner la chasse; [...]

to give the hunt

Autres renvoya devant la ville...

others sent.3sg in.front the city

'[The duke of Burgundy sent some of the horsemen that were with him to give chase...] He sent others to the front of the city...' (de Commynes, Mémoires, p.107)

In (18), the topic constituent ceste assemblee corresponds to an $\mathrm{AB}$ constituent, where only its reference back to a group of personalities is relevant. On the other hand, autres, in (19), is a ст constituent. Observe that the topic antecedents or anchors, boldfaced in the contexts provided between square brackets, differ only in contrast between the members of the inferred partially-ordered set presupposed in (19), which is \{groups of knights\}, to be compared with \{Burgundian nobles\} in (18) (see Birner and Ward 1998 for more information on partially-ordered sets and their pragmatic functions). 
In the examples of left dislocation found in this text, there is always a contrastive relation between the topic and other members of the partially-ordered set. This relation can be either implicit or explicit, as in (20).

(20) [Et ja estoit commencée une forte et
and already was.3sG begun.PTCP a important and
grosse escharmouche au $\quad$ bout du village de Montlehery,
large skirmish at.the end of.the village of Montlhéry,
toute d'archiers d'ung costé et d'autre.]
all of = archers of a side and of = other
Ceulx de la part du Roy les conduisoit Poncet de Rivière...
those of the side of.the king them led.3sG Poncet de Rivière
'[And a large skirmish had already begun at the end of the village of Montlhéry, com-
posed of archers on both sides.] Poncet de Rivière led those on the king's side.'

(de Commynes, Mémoires, p.25)

Left dislocation therefore seems to be in competition with contrastive topicalization in this grammar, in the sense that both were apparently used in the same pragmatic context, unlike aboutness topicalization.

Let us now consider the second argument for hypothesis B, according to which only null pronouns can be used in argumental positions. To frame the discussion, we must first establish some technical assumptions about the argument position in relation to the derivation of topicalization and left dislocation. Most authors have assumed that the latter derivation involves base-generation of the topic in the left-periphery of the clause, with the topic and resumptive connected by coreference. In contrast, the classical derivation of topicalization implies $\mathrm{A}^{\prime}$ movement which leaves a null variable behind. This difference accounts for the fact that topicalization is sensitive to islands, but that dislocation is not, as demonstrated in the pair below, from Chomsky (1977: 91):

(21) a. * This book, I wonder [who read $t_{i}$ ].

b. As for this book ${ }_{i}$, I think [you should read $i t_{i}$ ].

The question at hand is whether there is a gap left by movement, or rather a pro, in the base position of the topic in Old French. I use $\mathrm{pro}_{i}$ to indicate a null pronoun that occurs (for various reasons) instead of a resumptive pronoun, and $t_{\mathrm{i}}$ to mark a gap left by movement, which is interpreted as a variable. In this regard, debate about the nature of null objects in Old French in comparison to those of Modern French has carried on for quite some time. The prevalent view was that all null objects should be analyzed as null pronouns (Arteaga 1998). Another view, that of Donaldson (2013), is that like (22), an example far easier to analyze when the null object is treated as a variable:

(22) Sa grand valor $_{i}$, ki purreit acunter $t_{i}$ ?

his great value, who can.COND.3sG measure?

'Who could measure his great value?'

(Chanson de Roland, 1.534, cited in Donaldson 2013: 79) 
Arteaga (1998) questioned the derivation of an example similar to (22), given a minimality restriction that should block the movement of the object over the $\mathrm{A}^{\prime}$ element $\mathrm{ki}$. Actually, topics cannot be found in such contexts in English: they are in complementary distribution with both focus constituents and $w h$-words, as first observed by Chomsky (1977). However, aboutness topicalization can be found in a context similar to (22) in European Portuguese, as discussed in Duarte (1987: 333) and illustrated in (23). ${ }^{8}$

$\begin{aligned} & \text { Esses livros } i, \text { a quem ofereceu } \\ & \text { these books, to whom offer.Pst.3sg }\end{aligned}$ the João $t_{i}$ ?
'To whom did João offer these books?'

The solution to this apparent inconsistency involves adopting a finer conception of Relativized Minimality, where it is posited that different sorts of topicalization may be derived cross-linguistically, the English type being encoded in a lower projection in the left periphery (Haegeman 2012).

The interim conclusion is that hypothesis B cannot be correct. Although the two constructions have similar structural environments, Old French topicalization differs from its Modern French counterpart, where it is found only in root contexts. Furthermore, their pragmatic contexts are distinct, in that aboutness topicalization, which does not involve a contrast between the members of an inferred partiallyordered set, was available in addition to contrastive topicalization and left dislocation. Ultimately, there are reasons to believe that null variables were present in Old French, in precisely the contexts where topicalization took place.

\subsection{Quantitative results}

Table 3 presents the data retrieved by the automated queries, before the exclusion of specific tokens. It gives a bird-eye view of the number of preverbal objects, from which ABs were then selected.

The data can be divided into two periods. In the texts from the $11^{\text {th }}$ and $12^{\text {th }}$ centuries, the proportion of OV was $20 \%$ or higher. From the $13^{\text {th }}$ century to the $16^{\text {th }}$ century, this percentage decreases to $10 \%$ or less. The OV percentages dwindled to less than $5 \%$ in the $15^{\text {th }}$ and $16^{\text {th }}$ centuries, after which this word order was completely abandoned.

It is questionable whether these results truly represent a case of linguistic change, given that the available texts from the $11^{\text {th }}$ and $12^{\text {th }}$ centuries are all in the form of poetry. The order may also depend on idiosyncratic features of the text, as the inconsistent percentages of $\mathrm{OV}$ found in the two poetry texts from the $11^{\text {th }}$ century imply.

\footnotetext{
${ }^{8}$ However, strong islands that show subjacency effects seem to block topicalization in European Portuguese. Additionally, a simpler derivation is used by Duarte (1987) than the one proposed by Raposo (1986), with a null operator between the topic and the null variable. Although Duarte does not explicitly mention a way to guarantee the operator-variable relation, I take the null operator to be the salient partially-ordered set that includes the topic (arguably located in [Spec,FrameP]).
} 


\begin{tabular}{|c|c|c|c|}
\hline & & OV & VO \\
\hline \multirow[t]{2}{*}{$11^{\text {th }}$ century } & Saint Léger & $42 \%(19)$ & $58 \%(26)$ \\
\hline & Vie de Saint Alexis & $20 \%(20)$ & $80 \%(88)$ \\
\hline \multirow[t]{2}{*}{$12^{\text {th }}$ century } & Chanson de Roland & $47 \%(335)$ & $53 \%(711)$ \\
\hline & Psautier d'Oxford & $23 \%(99)$ & $77(333)$ \\
\hline \multirow[t]{3}{*}{$13^{\text {th }}$ century } & de Clari & $8 \%(40)$ & $92 \%(481)$ \\
\hline & de Boron & $7 \%(19)$ & $93 \%(236)$ \\
\hline & Roman de Cassidorus & $5 \%(35)$ & $95 \%(609)$ \\
\hline \multirow[t]{2}{*}{$14^{\text {th }}$ century } & de Joinville & $10 \%(89)$ & $90 \%(761)$ \\
\hline & Froissard & $2 \%(16)$ & $98 \%(803)$ \\
\hline \multirow[t]{3}{*}{$15^{\text {th }}$ century } & Quinze joies du mariage & $1 \%(6)$ & $99 \%(439)$ \\
\hline & de Commynes & $3 \%(22)$ & $97 \%(597)$ \\
\hline & Cent nouvelles nouvelles & $4 \%(18)$ & $96 \%(472)$ \\
\hline \multirow[t]{3}{*}{$16^{\text {th }}$ century } & d'Étaples & $2 \%(11)$ & $98 \%(517)$ \\
\hline & de Mailles & $3 \%(8)$ & $98 \%(275)$ \\
\hline & de Valois & $0 \%(0)$ & $100 \%(226)$ \\
\hline Total & & $10 \%(740)$ & $90 \%(6,574)$ \\
\hline
\end{tabular}

Table 3: OV versus VO in root clauses of the base texts

Regardless, since OV is still found in the Psautier d'Oxford (1860 [ca. 1150]), a $12^{\text {th }}$ century prose text, the presence of OV may not be genre-specific.

Another perspective, shown in Figure 1 below, illustrates the relative frequency of informational roles century by century. ${ }^{9}$ The most noticeable change is the decline in new-information focus $(\mathrm{NF})$ occurrences, which become very rare in the $15^{\text {th }}$ century, and completely disappear by the $16^{\text {th }}$ century. The incidence of the other roles increases throughout this period, with a prevalence of ABs that decreases only in the $13^{\text {th }}$ century, at the same time that CFs rose in frequency. Lastly, CTs show fairly constant rates and are less common than the other roles.

The results in Figure 1 should be interpreted based on Table 3. More specifically, from the $13^{\text {th }}$ century on, the results indicate that preverbal topics and foci became marked, suggesting that NF came to be conveyed at the right of the clause, thus having an impact on the overall distribution of other marked constructions. Concretely, although the frequency of ABs analogously increased, its frequency decreased in the overall corpus. This picture is consistent with the results in Labelle and Hirschbühler (2012), showing that the number of preverbal foci diminished progressively in Old French.

\footnotetext{
${ }^{9}$ The interaction between century and verb position is significant for the $11^{\text {th }}$ through the $13^{\text {th }}$ century (Fischer exact test: $p=5.624 \mathrm{e}-09$ ) and for the $14^{\text {th }}-16^{\text {th }}$ century (Fischer exact test: $p=0.003927)$.
} 


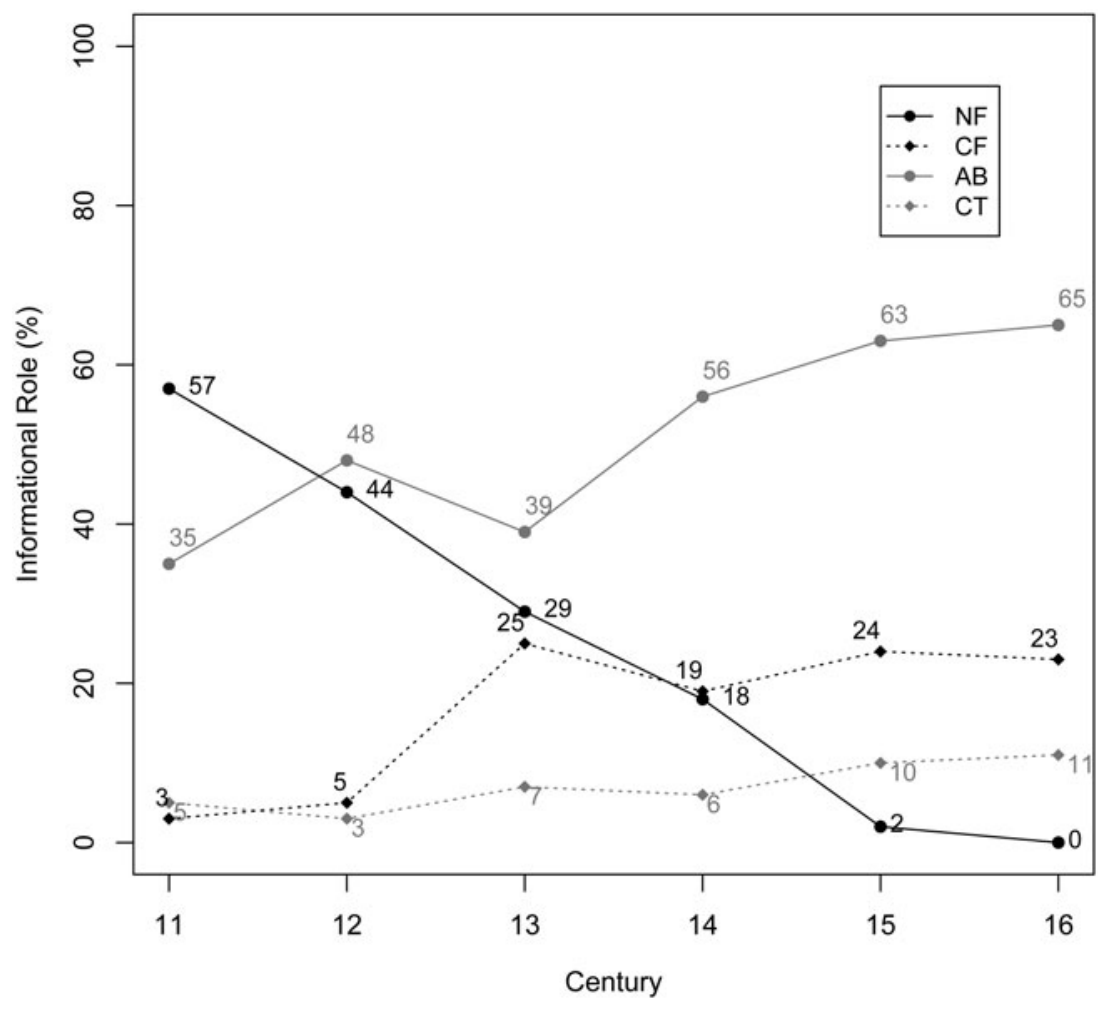

Figure 1: Distribution of informational roles by century (in percentage)

The next two tables shine a light on preverbal objects that are ABs, which correspond to half of the collected data and the theme of this paper. Table 4 correlates these numbers with subject realization in each century. ${ }^{10}$

ABS usually occur in clauses with referential null subjects. Their overall mean $(69 \%)$ rises significantly (to $88 \%$ ) in the $12^{\text {th }}$ century. A similar peculiarity also occurs with postverbal subjects, which are usually less frequent than null subjects, but whose frequencies exceed $50 \%$ for the $13^{\text {th }}, 14^{\text {th }}$ and $16^{\text {th }}$ centuries. This variable is relevant, as it may indicate whether ABs are indeed related to a V2 structure and understood as entwined with V-to-C movement, since this phenomenon should trigger subject inversion.

\footnotetext{
${ }^{10}$ The interaction between century and subject realization is significant for the $11^{\text {th }}-13^{\text {th }}$ century (Fischer exact test: $p=6.993 \mathrm{e}-13$ ) and for the $14^{\text {th }}-16^{\text {th }}$ century (Fischer exact test: $p=0.01644$ ).
} 


\begin{tabular}{|c|c|c|c|}
\hline & Preverbal S & Postverbal S & Null S \\
\hline $11^{\text {th }}$ century & $15 \%(2)$ & $23 \%(3)$ & $61 \%(8)$ \\
\hline $12^{\text {th }}$ century & $6 \%(12)$ & $6 \%(11)$ & $88 \%(163)$ \\
\hline $13^{\text {th }}$ century & $11 \%(3)$ & $66 \%(18)$ & $22 \%(6)$ \\
\hline $14^{\text {th }}$ century & $10 \%(6)$ & $65 \%(40)$ & $24 \%(15)$ \\
\hline $15^{\text {th }}$ century & $8 \%(2)$ & $35 \%(9)$ & $58 \%(15)$ \\
\hline $16^{\text {th }}$ century & $0 \%(0)$ & $76 \%(13)$ & $23 \%(4)$ \\
\hline Total & $7 \%$ & $28 \%(94)$ & $64 \%(211)$ \\
\hline
\end{tabular}

Table 4: Subject realization with aboutness topics in root clauses of the base texts

Table 5 pursues the same rationale; it examines whether there is a potential connection between object ABs and the V2 effect. ${ }^{11}$ Although there were more tokens with $\mathrm{V} 2$ than there were with $\mathrm{V}>2$ throughout our dataset, the percentage of $\mathrm{V}>2$ still amounted to around $40 \%$ of the catalogued cases in the $11^{\text {th }}$ and $15^{\text {th }}$ centuries.

Further analysis of the $\mathrm{V}>2$ tokens revealed that most of them correspond to the XOV type (33 tokens), followed by OXV (11 tokens), OSV (10) and SOV (8). Most OSV cases have a pronominal subject.

These results show that aboutness topicalization strongly correlates with postverbal subjects and V2 during the period when postverbal subjects were in use. In addition, Figure 1 demonstrates that new-information focalization disappeared by the end of the $14^{\text {th }}$ century, whereas aboutness topicalization was still in use until the $16^{\text {th }}$ century. Consequently, hypothesis A does not answer the research question. Its formulation probably did not take into account the distinction between preverbal topics and foci, which is now better understood. At any rate, ABs seem to be closely associated with the very fate of V2.

\section{Aboutness tOPICS AND THE FATE OF V2}

In this section, I discuss the implications of the results in the context of a previous analysis of the dissolution of the V2 system, to give an explanatory-based account for this change. From there, I develop an explanation for the demise of topicalization, based on the assumption that a syntactic change in Middle French caused the loss of aboutness topicalization. Unlike the loss of new-information focalization, this change cannot be explained by prosody specifically (i.e., the loss of sentence-initial stress; see Marchello-Nizia 1995, among others). Although topicalized constituents must be stressed by a particular intonation, prosody alone does not determine their very occurrence, as opposed to (some) focalized constituents.

\footnotetext{
${ }^{11}$ The interaction between century and verb position was not significant for the $11^{\text {th }}-13^{\text {th }}$ century (Fischer exact test: $p=0.2148$ ), but it was indeed significant for the $14^{\text {th }}-16^{\text {th }}$ century (Fischer exact test: $p=0.000411$ ).
} 


\begin{tabular}{lcc}
\hline \hline & $\mathrm{V} 2$ & $\mathrm{~V}>2$ \\
\hline $11^{\text {th }}$ century & $61 \%(8)$ & $38 \%(5)$ \\
$12^{\text {th }}$ century & $78 \%(145)$ & $22 \%(41)$ \\
$13^{\text {th }}$ century & $85 \%(23)$ & $15 \%(4)$ \\
$14^{\text {th }}$ century & $88 \%(54)$ & $12 \%(7)$ \\
$15^{\text {th }}$ century & $57 \%(15)$ & $43 \%(11)$ \\
$16^{\text {th }}$ century & $100 \%(17)$ & $0 \%(0)$ \\
Total & $\mathbf{7 9 \% ( 2 6 2 )}$ & $\mathbf{2 1 \% ( 6 8 )}$ \\
\hline \hline
\end{tabular}

Table 5: Verb position with aboutness topics in root clauses of the base texts

\subsection{A further hypothesis on topics and V2}

To ensure the accuracy of the analysis of aboutness topics in Old French, the parallelphases hypothesis, first put forward by Poletto (2006) and elaborated upon in Mensching (2012), has been incorporated here because of the finer distinctions it makes between informational roles. This particular hypothesis correlates the availability of topicalization with vP scrambling, a construction especially found in compound tenses and illustrated in (24) for Old Italian.
(24) ch'egli avea il maleficio commesso that=he had.3sG the crime committed 'that he had committed the crime'

(Giamboni, Fiore di rettorica, 1994[1292]: 34, cited in Poletto 2006:265)

Mensching (2012) equates the loss of an optional movement feature in the phase head $\mathrm{v}$ with the loss of topicalization. Example (25a) shows the derivation in Old Spanish, and (25b) the one in Modern Spanish, where a clitic phrase (clP) replaces $\mathrm{vP}$ in its role:

$$
\begin{aligned}
& \text { (25) a. [IP } \mathrm{NP}_{\mathrm{DO}} \quad\left[{ }_{\mathrm{vP}} \mathrm{NP}_{\mathrm{DO}} \ldots\left[\begin{array}{ll}
\left.\mathrm{NP}_{\mathrm{DO}}\right] & \ldots]
\end{array}\right]\right. \\
& \text { b. [CP } \left.\mathrm{NP}_{\mathrm{DO}} \quad\left[_{\mathrm{clP}} \mathrm{DP}_{\mathrm{DO}} \mathrm{cl}\left[{ }_{\mathrm{IP}}\left[_{\mathrm{vP}} \mathrm{DP}_{\mathrm{DO}}\right]\right]\right]\right]
\end{aligned}
$$

According to the minimalist account of syntactic phases (Chomsky, 2001), any clause is divided into two domains that are visible to the interfaces. Similarly, this proposal also presupposes that, to be displaced to the left periphery, a topic constituent must stop at each intervening phase edge. In the basic representations above, the intermediary $\mathrm{NP}_{\mathrm{DO}}$ stays in the position where scrambled objects are found. For some reason, the topical NP does not always complete its movement to the CP periphery; it sometimes stops in the lower vP periphery. Thus, this theory predicts that in the period when there were fronted objects, we should also find scrambled objects with similar properties.

With an emphasis on providing an explanation for the loss of topicalization, this proposal assumes, similarly to hypothesis A, that this shift is the cause of the demise of the V2 system, with an additional step: the loss of $\mathrm{vP}$ scrambling. However, by doing so, it formalizes a functional observation related to the use of certain marked 
constructions, a proposal that naturally implies that pragmatic changes trigger syntactic changes, going against basic generative premises. An additional pitfall in Mensching's (2012) specific rendering of the hypothesis for this change is the prediction that topicalization is replaced by left dislocation. This conjecture goes against empirical evidence found in the base texts studied - the latter construction remains very marked until the Renaissance period.

The proposal opens up new problems - germane to the parallelism between topicalization and scrambling - whose proper discussion goes beyond this text. Not much is known about vP scrambling, but Zaring (2010) observes that OV order in infinitival and participial domains continued to be frequent in the $13^{\text {th }}$ century, when OV order was rather rare in finite contexts. This finding suggests that this type of OV is relatively independent of aboutness topicalization. To verify this, I have queried for participles in compound tenses and for "restructuring" infinitives, which project up to $\mathrm{vP}$, in the base texts written in the $15^{\text {th }}$ and $16^{\text {th }}$ centuries. ${ }^{12}$ The results show that scrambled NPs are similar either to focus or to topics, as the examples in (26) and (27) suggest.

(26) ung prestre ne doit ame tuer a priest NEG should soul kill 'a priest should not kill a soul.'

(Cent nouvelles nouvelles, p.62)

et povez l'absence de mon bon mary supplier...
and could the=absence of my good husband compensate
'and you could compensate the absence of my good husband...'

(Cent nouvelles nouvelles, p.574)

Nevertheless, evidence of scrambled topics ceases to be found by the end of the $15^{\text {th }}$ century, although the presence of aboutness topicalization was detected in some of the later texts. In any case, scrambled foci of quantifiers such as plus, jamais, aucunement persisted in Renaissance French:

(28) J'ay beaucoup entendu de $\quad$ son affaire.
I= have much understand.PTCP of his business
'I have understood much of his business.'

(de Mailles, Histoire du Seigneur de Bayart, p.108)

This construction was retained, and is still accepted in Modern French (Abeillé and Godard 2004), although no counterpart in the CP periphery has been reported. ${ }^{13}$ This may suggest that $\mathrm{vP}$-scrambled topics and $\mathrm{CP}$-moved topics can be independently generated, and encode different sorts of elements. ${ }^{14}$ Therefore, vP scrambling

\footnotetext{
${ }^{12}$ Scrivner (2015) indeed shows that OV in "restructuring" infinitives is less frequent than in other types of infinitive contexts. See also Zaring (2011) for a specific derivational proposal.

${ }^{13}$ Sleeman (2012) discusses some related cases in Modern French, but all of them include the verb être. Poletto's (2006) suggestion that quantifiers should be assigned a specific position in the cartographic structure does not change this problem.

${ }^{14}$ This is also what some scholars working on information structure have found out with respect to the distinction between left dislocation and right dislocation: while left dislocation may connect to the context by different types of partially-ordered sets, right dislocation is
} 
needs to be further studied, but it is unlikely that it had an impact on the dynamics of change, or precisely, that a shift in the $\mathrm{vP}$ periphery had an impact on the $\mathrm{CP}$ periphery.

\subsection{An alternative proposal}

In order to build an alternative proposal, it is necessary to bear in mind that there are two types of topics, moved and base-generated, as discussed in Section 3.2. Salvesen (2013) conveys this, to a degree, by saying that topics are invisible to the V2 configuration. If we adopt Benincà and Poletto's (2004) cartographic proposal for the left periphery, the only elements that can count as being in the first clausal position thus occupy either SpecFocP or SpecFinP. The explanation for this invisibility is the base-generation of the topic in the peripheral position, being coreferential to a pro argument inside the clause. ${ }^{15}$ For Salvesen (2013), elements occupying SpecFinP are informationally "neutral."

There are two ways the term "neutral" can be understood. Some use it to refer to constituents that are typically destressed and realized in a pronominal form: familiar topics (FM; see Frascarelli and Hinterhölzl 2007). This cannot be the relevant sense of "neutral", as not only familiar topics and foci correlate with V2, but also aboutness topics, as shown in Table 5 above. In some centuries, they even showed a strong correlation with postverbal subjects, a sign of Germanic inversion occurring when the subject is adjacent to the verb:

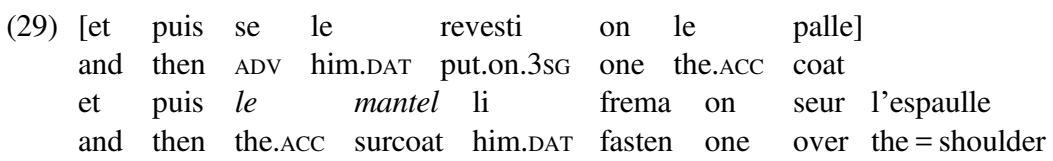

'And then they put the coat on him, then they fastened the surcoat over his shoulders.'

(de Clari, La conquête de Constantinople, p.95)

In (29), the constituent le mantel ('the surcoat') illustrates a typical case of $\mathrm{AB}$, used in a descriptive context where the king wears different pieces of clothing. Therefore, a more reasonable proposal is to interpret "neutral" as nonspecific. Hence, I adopt the idea that [Spec,FinP] is a multifunctional position, as other traditional accounts for V2 have done (e.g., Roberts 2004). A product of this idea is shown in the clause structure in (30), where syntactic positions are connected to informational roles, using a simplified set of projections - up arrow indicates Merge, and left arrow represents Move; ForceP is not projected because this structure applies to root contexts:

felicitous only when an identity relation holds between the topic and its anchor. Thus, assigning the same properties to the CP periphery and to the vP periphery is misleading (de Cat 2007, López 2009).

${ }^{15}$ Salvesen (2013) also discusses an alternative derivation, according to which topics could move directly to a left-peripheral position above [Spec,FocusP]. For the sake of simplicity, I will keep to the more traditional base-generation analysis for left dislocation. 
$\begin{array}{lllll}\text { (30) } & \text { [FrameP } & \text { [TopicP }_{\text {TFocusP }} & {[\text { FinP }} & \text { [IP } \\ \uparrow_{\mathrm{FS}} & \leftarrow \mathrm{AB}, \mathrm{CT} & \leftarrow \mathrm{CF}, \mathrm{NF} & \leftarrow \mathrm{AB}, \mathrm{CT} & \leftarrow \text { FM, } \\ & & & \mathrm{CF}, \mathrm{NF} & \text { Scrambled XP }\end{array}$

The constituent that moves to [Spec,FinP] is one of the informational elements that appear below FinP in the scheme in (30), from where they move further, either to [Spec,TopicP] or to [Spec,FocusP], depending on the type of information they convey.

In addition, I adapt Frey's (2004) framework, according to which some elements in the left periphery move by True A'-movement or by Formal Movement. This distinction is based on the motive for movement: in true $\mathrm{A}^{\prime}$-movement, it is guided by a criterial feature, whereas in formal movement no interpretative effect is involved, only the need to value the EPP feature of Fin. This last case implies movement of either a FM or a scrambled XP, and occurs if none of the elements shown below FinP in (30) is available in the sentence. ${ }^{16}$ Unlike in Frey's (2004) account, there is no need to assume an intermediary KontrP projection for items with criterial features, understood as contrastive. Instead, these are assumed to have priority in their checking over formal features, implying that Formal Movement will occur if and only if there is no [тоРіс], [FOCus] or [CONTRAST] feature, nor a combination thereof, involved.

This proposal predicts that, whenever there is a preverbal object, V2 is the predominant order. Nevertheless, V3 orders such as XOV and OXV are also possible, as in the examples below:

(31) mes de tel mestier riens ne sai... but of this matter nothing NEG know.1sG

'but regarding this matter, I know nothing [at all]...' (Roman de Cassidorus, p.356)

(32) Branches d'olive en vos mains portereiz... branches of =olive in your hands carry.Fut.2PL

'You will carry olive branches in your hands.'

(La chanson de Roland, st.13)

In (31), X corresponds to FS, and O, to NF. In (32), O embodies the AB role, whereas $\mathrm{X}$ plays the role of $\mathrm{CF}$. This example is interesting because it indicates that locative items may function either as FS or as $\mathrm{CF}$, while a contrastive interpretation is required in the configuration above. Examples (33) and (34) show SOV and OSV orders respectively:

(33) $\mathrm{Li}$ rei des Arabiens e de Saba duns amerrunt the.NOM kings of.the Arabs and of Saba gifts bring.Fut.3PL 'The kings of the Arabs and of Saba will bring gifts.'

(Psautier d'Oxford, ch.71, 1.10)

(34) Les chars crues il mettent entre leur celles et leur the.PL meat.PL raw.PL they put between their saddles and their paniaus baskets

\footnotetext{
${ }^{16}$ I consider the scrambled XP to be a subcase of what other authors call a stylistically fronted element (see Mathieu 2013 and Salvesen 2013 for different views on this phenomenon). See also Labelle and Hirschbühler (2014) for a critical review of the term 'stylistic fronting'.
} 
'They put the raw meat between their saddles and their baskets.'

(de Joinville, Histoire de Saint Louis, p.239)

Unlike the cases with XOV and OXV, SOV and OSV orders were unevenly distributed through time. SOV was apparently conventional in the $11^{\text {th }}$ and $12^{\text {th }}$ centuries, whereas OSV was more frequent from the $13^{\text {th }}$ century onwards. Thus I interpret that different grammars, involving different verb positions, are involved in these cases. In the former period there was a V-final structure ( $\mathrm{V}$ in situ) competing with the $\mathrm{V}$-to-C grammar. On the other hand, in the latter period V-to-I was in competition with V-toC. Therefore in (33), the subject is an $\mathrm{AB}$, and the object is NF, but only the subject moves into the left periphery, because it is the higher element in the vP phase. In (34), the object is an $\mathrm{AB}$, and the subject is a FM; only the object moves, because it is equidistant from the subject when in an IP-scrambling position, which I assume was lost at the same time as NF.

I also assume that loss of verb movement came about with the change in null subjects and is linked with the loss of new-information focalization (see, respectively, Vance 1997 and Labelle and Hirschbühler 2012). The OSV order, most common in the Middle French period, is understood as indicating a V-to-I analysis, hence triggering the reanalysis that established V-to-I as an innovative structure. Consequently, the loss of aboutness topicalization should be seen as an an effect of this change; and not its trigger, which naturally gives rise to the a third hypothesis, Hypothesis $\mathrm{C}$.

Hypothesis C: The V-to-I grammar of Renaissance French blocked the derivation of aboutness topicalization.

I adhere to the framework of phase theory (Chomsky 2001, among others), further developed in den Dikken (2007) and discussed in Pesetsky (2007) regarding the notion of "phase extension." According to den Dikken, the position into which a phase head moves determines the limits of a syntactic phase. Therefore, if verb movement stops at $\mathrm{I}^{0}$, [Spec,IP] becomes the phase edge, as in (35b).

(35) a. [CP [IP \{PhaseEdge [vP $\mathrm{V}+v \quad[\mathrm{VP} \forall]]]$

b. [CP \{PhaseEdge [IP $\left.\left.\mathrm{V}+v+\mathrm{T}\left[{ }_{\mathrm{vP}} \mathrm{V}+\left[_{\mathrm{VP}} \forall\right]\right]\right]\right]$

As Pesetsky (2007) points out, the movement triggered by $\mathrm{I}^{0}$ in (35b) counts as an $\mathrm{A}^{\prime}$ movement; it is a property of phasal heads. The adoption of the phase extension model combined with Rizzi's (1990) Relativized Minimality condition implies that an intervening governor, the subject, blocks a government relation of the same kind. Notice that both ABs and FMs have a [TоPIC] feature, but this feature is already checked in [Spec,IP], as there is no difference in criterial features between the two. Therefore, an $\mathrm{AB}$ cannot move over a subject.

Two implications stem from the proposal relating V-to-C movement and aboutness topicalization. The first one is that only aboutness topics are affected, although contrastive focalization and contrastive topicalization have disappeared altogether from Renaissance French, according to the dataset used here. These elements are featurally distinct from the subject because they carry a [CONTRAST] feature and both [CONTRAST] and [TOPIC] features, respectively; thus Relativized Minimality does not 
block their movement. Such an implication is welcome because preverbal cTs are possible in Modern French, and preverbal CFs are possible in other Modern Romance languages, like Spanish. ${ }^{17}$

The second implication of the proposal is that only languages with V-to-C movement may have aboutness topicalization. This is a strong prediction, and a discussion of it would surpass the goals of the present article. Among Romance and Germanic languages, this seems to be correct. For instance, English adheres to this prediction so much so that the very existence of topicalization is sometimes put into question (Prince 1999; see also Speyer 2010 for the correlation between contrast and topicalization in English). Portuguese, on the contrary, remains a noticeable exception. However, it also happens to have archaic feature remnants, such as enclitic pronouns in finite clauses, which are associated with the activation of the left periphery, and specifically with V-to-C movement (Raposo 2000 and others).

Since the syntax is frequently opaque to informational properties, it may or may not allow the movement of aboutness topics, as well as of other informational categories. This explains in part the existence of cross-linguistic variation on how such categories are expressed.

\section{ConClusion}

In this paper, I have discussed aboutness topics in the history of French to understand their disappearance in preverbal position. To do so, I have conducted a corpus-based study of preverbal accusative objects in fifteen texts from the Old and Middle French periods up to Renaissance French, from the both qualitative and quantitative points of view. The data indicate that contrastive topicalization and left dislocation used to encode the same informational role, that is to say, ст (contrastive topic). Second, contrastive focalization and aboutness topicalization were lost by the end of the $16^{\text {th }}$ century. Finally, new-information focalization was lost by the $14^{\text {th }}$ century, with only traces remaning in the $15^{\text {th }}$ century.

Based on the available data, I have concluded that V2 holds in Old and Middle French, as there is almost no competition with other data that indicate an older V-final grammar or a newer V-to-I grammar. In this scenario, [Spec,FinP] is a multifunctional position that must be realized by some constituent moved into it. True $\mathrm{A}^{\prime}$ Movement takes precedence over Formal Movement, which only selects the closest element available. In this sense, there is an implicit connection between the disappearance of aboutness topicalization and the fate of V2: once the V-to-C grammar was reanalyzed as V-to-I, the movement of aboutness topics was blocked by the Relativized Minimality restriction, assuming Phase Extension.

\footnotetext{
${ }^{17}$ This follows automatically from the definition of Relativized Minimality adopted, without the need for any further proviso, such as the distinction between lexically-selected EPP and "free" EPP on a phase head, as in Mensching (2012: 41), where free EPP would be related to focus and $w h$-words. Notice also that the derivation of clefting, which seems to have replaced Contrastive Focalization in Modern French, also involves movement of the clefted XP over the subject.
} 
This view of the change is different from the prevalent one, according to which aboutness topics disappeared for independent reasons and caused the loss of V2. The reason to bring forward this new proposal has to do with the assumption that informational-structural notions should not change independently. Instead, the morphosyntactic profile of each language constrains the way information structures are expressed. If we take seriously the generative premise that syntax is relatively autonomous from pragmatics, the diachronic study of information structure should consider marked constructions as diagnostics or effects of more general grammatical phenomena.

\section{SOURCES}

de Boron, Robert. Roman du Graal. Ed. William A. Nitze, 1927. Paris: Honoré Champion. [ca. 1190].

Cent nouvelles nouvelles. Ed. Franklin P. Sweetser, 1964. Geneva: Droz. [1450].

Chanson de Roland. Ed. Gérard Moignet, 1972. Paris: Bordas. [ca. 1100].

de Clari, Robert. Conquête de Constantinople. Ed. Philippe Lauer, 1924. Paris: Honoré

Champion. [ca. 1205].

de Commynes, Philippe. Mémoires. Tome I Ir (1464-1474). Ed. Joseph Calmette, 1964. Paris:

Les Belles Lettres. [1498].

d'Étaples, Jacques Lefèvre. Nouveau Testament. 1970. Paris: Mouton. [1523].

Froissart, Jean. Chroniques. Ed. George T. Diller, 1972. Geneva: Droz. [1373].

Giamboni, Bono. 1994. Fiore di rettorica (redazione beta). Ed. Gian Battista Speroni. Pavia:

Dipartimento de Scienza della Letteratura e dell'Arte medioevale e moderna, 3-107.

[1292]. (Cited in Poletto 2006)

de Joinville, Jean. Histoire de Saint Louis. Ed. Natalis de Wailly, 1868. Paris: Renouard.

[1309].

de Mailles, Jacques. Histoire du Seigneur de Bayart. 1927. Paris: Droz \& Heffer. [1527].

Psautier d'Oxford. Ed. Francisque Michel, 1860. Oxford: Oxford University Press. [ca. 1150]. Quinze joies du mariage. Ed. Jean Rychner, 1963. Geneva: Droz. [1450].

Roman de Cassidorus. Ed. Joseph Palermo, 1964. Paris: Picard. [1267].

Saint Léger. Ed. Joseph Linskill, 1937. Paris: Droz. [ca. 980].

de Valois, Marguerite. Correspondance 1569-1614. Ed. Eliane Viennot, 1998. Paris:

Champion. [1569-1614].

Vie de Saint Alexis. Ed. Christopher Storey, 1968. Geneva: Droz. [ca. 1090].

\section{REFERENCES}

Abeillé, Anne, and Danièle Godard. 2004. The syntax of French adverbs without functional projections. In Current studies in comparative Romance linguistics, ed. Martine Coene, Gretel de Cuyper, and Yves d'Hulst, 11-42. Amsterdam: John Benjamins.

Adams, Marianne. 1987. From Old French to the theory of pro-drop. Natural Language and Linguistic Theory 5: 1-32.

de Andrade, Aroldo. 2015. On the emergence of topicalisation in European Portuguese: A study at the syntax-information structure interface. Ms., University of Campinas. 
Arteaga, Deborah. 1998. On null objects in Old French. In Romance linguistics: Theoretical perspectives, ed. Armin Schwegler, Bernard Tranel, and Myriam Uribe-Etxebarria, 1-11. Amsterdam: John Benjamins.

Barnes, Betsy. 1985. The pragmatics of Left Detachment in spoken Standard French. Amsterdam: John Benjamins.

Benincà, Paola, and Cecilia Poletto. 2004. Topic, focus and V2: Defining the CP sublayers. In The structure of IP and CP: The cartography of syntactic structures, Volume 2, ed. Luigi Rizzi, 52-75. Oxford: Oxford University Press.

Bianchi, Valentina, and Mara Frascarelli. 2010. Is Topic a root phenomenon? Iberia 2: 43-88. Birner, Betty J., and Gregory Ward. 1998. Information status and noncanonical word order in English. Amsterdam: John Benjamins.

Blasco, Mylène. 1997. Pour une approche syntaxique des dislocations. French Language Studies 7(1): 1-21.

Casielles-Suárez, Eugenia. 2004. The syntax-information structure interface: Evidence from Spanish and English. New York: Routledge.

de Cat, Cécile. 2007. French dislocation: Interpretation, syntax, acquisition. Oxford: Oxford University Press.

Chomsky, Noam. 1977. On wh-movement. In Formal syntax, ed. Peter Culicover, Thomas Wasow, and Adrian Akmajian, 71-132. New York: Academic Press.

Chomsky, Noam. 2001. Derivation by phase. In Ken Hale: A life in language, ed. Michael Kenstowicz, 1-52. Cambridge, MA: MIT Press.

Cinque, Guglielmo. 1990. Types of $A^{\prime}$-dependencies. Cambridge, MA: MIT Press.

den Dikken, Marcel. 2007. Phase extension: Contours of a theory of the role of head movement in phrasal extraction. Theoretical Linguistics 33(1): 1-42.

Donaldson, Bryan. 2013. Null objects in Old French. In Research on Old French: The state of the art, ed. Deborah Arteaga, 61-86. Dordrecht: Springer.

Duarte, Maria Inês P. S. 1987. A construção de topicalização na gramática do português: regência, ligação e condições sobre movimento [The topicalization construction in the grammar of Portuguese: Government, binding, and conditions on movement]. Doctoral dissertation, University of Lisbon.

Erteschik-Shir, Nomi. 1997. The dynamics of focus structure. Cambridge: Cambridge University Press.

Frascarelli, Mara. 2000. The syntax-phonology interface in focus and topic constructions in Italian. Dordrecht: Kluwer.

Frascarelli, Mara, and Roland Hinterhölzl. 2007. Types of topics in German and Italian. In On information structure, meaning and form, eds. Susanne Winkler and Kerstin Schwabe, 87-116. Amsterdam: John Benjamins.

Foulet, Lucien. 1919. Petite syntaxe de l'ancien français. Paris: Honoré Champion.

Frey, Werner. 2004. The grammar-pragmatics interface and the German prefield. Sprache und Pragmatik $52: 1-39$.

Götze, Michael, Thomas Weskott, Cornelia Endriss, Ines Fiedler, Stefan Hinterwimmer, Svetlana Petrova, Anne Schwarz, Stavros Skopeteas, and Ruben Stoel. 2007. Information structure. Interdisciplinary studies on information structure 7: Information structure in cross-linguistic corpora: Annotation guidelines for phonology, morphology, syntax, semantics and information structure, ed. Stephanie Dipper, Michael Götze, and Stavros Skopeteas, 147-187.

Guillot, Céline. (dir.) 2014. BFM: Base de Français Médiéval. Lyon: ENS de Lyon, Laboratoire ICAR. < http://txm.bfm-corpus.org >. 
Haegeman, Liliane. 2012. Adverbial clauses, main clause phenomena, and the composition of the left periphery. Oxford: Oxford University Press.

Haug, Dag T., Hanne Martine Eckhoff, and Eirik Welo. 2014. The theoretical foundations of givenness annotation. In Information structure and word order in Old Germanic and Old Romance, ed. Kristin Bech and Kristin Eide, 17-52. Amsterdam: John Benjamins.

Hirschbühler, Paul. 1975. On the source of lefthand NPs in French. Linguistic Inquiry 6(1): $155-165$.

Krifka, Manfred. 2007. Basic Notions of Information Structure. Interdisciplinary Studies on Information Structure 6: The notions of information structure, ed. Caroline Féry, Gisbert Fanselow, and Manfred Krifka, 13-55.

Labelle, Marie, and Paul Hirschbühler. 2005. Changes in clausal organization and the position of clitics in Old French. In Grammaticalization and parametric change, ed. Montse Batllori and Francesc Roca, 60-71. Oxford: Oxford University Press.

Labelle, Marie, and Paul Hirschbühler. 2012. Topic and focus in Old French V1 and V2. Paper presented at the Diachronic Generative Syntax Conference, Philadelphia.

Labelle, Marie, and Paul Hirschbühler. 2014. Déplacement stylistique à gauche de verbes non conjugués en ancien et en moyen français. Corpus 13: 191-219.

López, Luis. 2009. A derivational syntax for information structure. Oxford: Oxford University Press.

Marchello-Nizia, Christiane. 1995. L'évolution du français: Ordre des mots, démonstratifs, accent tonique. Paris: Armand Colin.

Martineau, France. 2008. Un corpus pour l'analyse de la variation et du changement linguistique. Corpus 7: Constitution et exploitation des corpus d'ancien et de moyen français, ed. Céline Guillot, Serge Heiden, Alexei Lavrentiev, and Christiane Marchello-Nizia, $135-155$.

Martineau, France, Rodica Diaconescu, and Paul Hirschbühler. 2007. Le corpus Voies du français: de l'élaboration à l'annotation. In Le nouveau corpus d'Amsterdam, ed. Pierre Kunstmann and Achim Stein, 121-142. Stuttgart: Steiner.

Martineau, France, Paul Hirschbühler, Anthony Kroch, and Yves-Charles Morin. 2010. Corpus MCVF annoté syntaxiquement. <http://continent.uottawa.ca/fr/corpus/corpusmevf/structure/>

Mathieu, Éric. 2013. The Left Periphery in Old French. In Research on Old French: The state of the art, ed. Deborah Arteaga, 327-350. Dordrecht: Springer.

Mensching, Guido. 2012. Parameters in Old Romance word order: A comparative minimalist analysis. In Parameter theory and linguistic change, ed. Charlotte Galves, Sonia Cyrino, Ruth Lopes, Filomena Sandalo, and Juanito Avelar, 21-42. Oxford: Oxford University Press.

Pesetsky, David. 2007. Property delay. Theoretical Linguistics 33(1): 105-120.

Petrova, Svetlana, and Michael Solf. 2009. On the methods of information-structural analysis in historical texts: A case study on Old High German. In Information structure and language change: New approaches to word order variation in Germanic, ed. Roland Hinterhölzl and Svetlana Petrova, 121-160. Berlin: Mouton de Gruyter.

Poletto, Cecilia. 2006. Parallel phases: A study on the high and low left periphery of Old Italian. In Phases of interpretation, ed. Mara Frascarelli, 261-295. Berlin: Mouton de Gruyter.

Priestley, Leonard. 1955. Reprise constructions in French. Archivum Linguisticum 7: 1-28.

Prince, Ellen. 1999. How not to mark topics: 'Topicalization' in English and Yiddish. Ms., University of Pennsylvania.

Randall, Beth. 2005. CorpusSearch 2. <http://corpussearch.sourceforge.net> 
Raposo, Eduardo. 1986. On the null object in European Portuguese. In Studies in Romance linguistics, ed. Osvaldo Jaeggli and Carmen Silva-Corvalán, 373-390. Dordrecht: Foris.

Raposo, Eduardo. 2000. Clitic position and verb movement. In Portuguese syntax: New comparative studies, ed. João Costa, 266-297. Oxford: Oxford University Press.

Rickard, Peter. 1962. The word-order object-verb-subject in Medieval French. Transactions of the Philological Society 61(1): 1-39.

Rizzi, Luigi. 1986. Null objects in Italian and the theory of pro. Linguistic Inquiry 17(3): 501557.

Rizzi, Luigi. 1990. Relativized minimality. Cambridge, MA: MIT Press.

Rizzi, Luigi. 1997. The fine structure of the left periphery. In Elements of grammar: Handbook of generative syntax, ed. Liliane Haegeman, 281-337. Dordrecht: Kluwer.

Roberts, Ian. 2004. The C-system in Brythonic Celtic languages, V2 and the EPP. In The structure of CP and IP: The cartography of syntactic structures, Volume 2, ed. Luigi Rizzi, 297-328. Oxford: Oxford University Press.

Salvesen, Christine M. 2013. Topics and the left periphery: A comparison of Old French and Modern Germanic. In In search of universal grammar: From Old Norse to Zoque, ed. Terje Lohndal, 131-171. Amsterdam: John Benjamins.

Santorini, Beatrice, and Anthony Kroch. 2014. Penn supplement: Philological information about the French texts. Ms., University of Pennsylvania. <http://www.ling.upenn.edu/ beatrice/corpus-ling/frenchTexts.html>

Scrivner, Olga B. 2015. A probabilistic approach in historical linguistics: Word order change in infinitival clauses, from Latin to Old French. Doctoral dissertation, Indiana University.

Skårup, Povl. 1975. Les premières zones de la proposition en ancien français: Essai de syntaxe de position. Copenhagen: Akademisk Forlag.

Sleeman, Petra. 2012. Quantifier preposing in French and Italian as a root phenomenon: a syntactic or a pragmatic approach? Bucharest Working Papers in Linguistics 14(1): 5-22.

Speyer, Augustin. 2010. Topicalization and stress clash avoidance in the history of English. Berlin: Walter de Gruyter.

Steiner, Brittany D. J. 2014. The evolution of information structure and verb second in the history of French. Doctoral dissertation, Indiana University.

Taylor, Ann, and Susan Pintzuk. 2014. Testing the theory: Information structure in Old English. In Information structure and word order in Old Germanic and Old Romance, ed. Kristin Bech and Kristin Eide, 53-78. Amsterdam: John Benjamins.

Thurneysen, Rudolf. 1892. Zur Stellung des Verbums im Altfranzösischen [On the position of the verb in Old French]. Zeitschrift für Romanische Philologie 16: 289-307.

Troberg, Michelle. 2004. Topic-comment resumptive pronouns in Modern French and Old and Middle French. Toronto Working Papers in Linguistics 23(1): 133-156.

Vance, Barbara. 1997. Syntactic change in Medieval French. Dordrecht: Kluwer.

von Wartburg, Walther. 1946. Évolution et structure de la langue française. Berne: Francke.

Zaring, Laurie. 2010. Changing from OV to VO: More evidence from Old French. Ianua: Revista Philologica Romanica 10: 1-18.

Zaring, Laurie. 2011. On the nature of OV and VO order in Old French. Lingua 121(12): $1831-1852$. 


\section{APPENDiX A. NOTES ON DATA COLLECTION}

The selected texts were narratives, and most of them were written in prose style. At least two different texts were selected per century, making up about 8,000 base sentences for each century in most of the period $\left(12^{\text {th }}-16^{\text {th }}\right.$ century). Part of a text from the $14^{\text {th }}$ century, Froissart, was included to bring the number of sentences up to the required total.

The general clause type searched for was: root, declarative, and active. There were two other restrictions regarding clause type:

- Clauses with a copula, either equative or predicative, were excluded, because they favor the use of preverbal objects.

- Ambiguous sentences with a V-final order were excluded from the tokens in the $11^{\text {th }}$ and $12^{\text {th }}$ centuries.

The following three restrictions were applied to the selection of fronted NP objects (where NP may include a free relative, usually with generic reference; notice that the corpus annotation scheme does not differentiate NP from DP):

\begin{tabular}{|c|c|c|c|c|c|}
\hline Century & Reference & Type & Corpus & Sentences & Tokens \\
\hline \multirow[t]{2}{*}{11} & Saint Léger & poetry & MCVF & 181 & 17 \\
\hline & Vie de Saint Alexis & poetry & Penn & 546 & 20 \\
\hline \multicolumn{2}{|l|}{ Total } & & & 727 & 37 \\
\hline \multirow[t]{2}{*}{12} & Chanson de Roland & poetry & MCVF & 3,705 & 285 \\
\hline & $\begin{array}{l}\text { Psautier d'Oxford } \\
\text { (up to chapter } 82 \text { ) }\end{array}$ & prose & BFM & 2,672 & 99 \\
\hline \multicolumn{2}{|l|}{ Total } & & & 6,377 & 384 \\
\hline \multirow[t]{3}{*}{13} & de Clari & prose & $\mathrm{MCVF}$ & 2,342 & 23 \\
\hline & de Boron & poetry & MCVF & 1,331 & 17 \\
\hline & Roman de Cassidorus & prose & MCVF & 4,398 & 29 \\
\hline \multicolumn{2}{|l|}{ Total } & & & 8,071 & 69 \\
\hline \multirow[t]{2}{*}{14} & de Joinville & prose & Penn & 4,317 & 88 \\
\hline & Froissard (up to chapter 82) & prose & Penn & 4,176 & 20 \\
\hline \multicolumn{2}{|l|}{ Total } & & & 8,493 & 108 \\
\hline \multirow[t]{3}{*}{15} & Quinze joies du mariage & prose & MCVF & 2,445 & 5 \\
\hline & $\begin{array}{l}\text { Cent nouvelles nouvelles } \\
\text { (up to chapter } 32 \text { ) }\end{array}$ & prose & $\mathrm{MCVF}$ & 3,646 & 18 \\
\hline & de Commynes & prose & Penn & 2,354 & 18 \\
\hline \multicolumn{2}{|l|}{ Total } & & & 8,445 & 41 \\
\hline \multirow[t]{3}{*}{16} & d'Étaples & prose & Penn & 2,861 & 10 \\
\hline & de Mailles & prose & Penn & 3,079 & 16 \\
\hline & de Valois & prose & Penn & 1,122 & 0 \\
\hline \multicolumn{2}{|l|}{ Total } & & & 7,062 & 26 \\
\hline \multicolumn{2}{|c|}{ Overall Total } & & & 39,139 & 665 \\
\hline
\end{tabular}


- Pronominal (personal and demonstrative) objects are excluded because their syntax and semantics is different from those of non-pronominal objects;

- Only clauses with a single NP object are included (i.e., ditransitives with two NP objects are excluded, although those with a dative pronominal and an accusative NP in preverbal position are included). This decision was made in order to avoid double categorization of two preverbal objects that could eventually skew the results;

- Appositive NPs are not separately counted, because they have the same referent as the nominal they modify.

Table A1 provides an overview of the texts included in the analysis: century of composition, full title, type, source (among the three base corpora mentioned in the text), the number of sentences in each base text and the number of final tokens, after the data were filtered according to the criteria given above.

\section{APPENDIX B. CORPUSSEARCH QUERIES}

The query used in CorpusSearch to find the number of object-verb tokens, object being an accusative NP, is shown in (B1). For verb-object order, the query in (B2) was used. For further information on how to elaborate and run CorpusSearch command files, see Randall (2005).

(B1) Query for Nominal OV

node: IP-MAT*

query: (IP-MAT* iDoms NP-ACC*)

AND (IP-MAT* iDoms AJ|EJ|LJ|MDJ|VJ)

AND (NP-ACC* Precedes AJ|EJ|LJ|MDJ|VJ)

AND (NP-ACC* iDoms !CL)

AND (NP-ACC* iDoms !PRO)

(B2) Query for Nominal VO

node: IP-MAT*

query: (IP-MAT* iDoms NP-ACC*)

AND (IP-MAT* iDoms AJ|EJ|LJ|MDJ|VJ)

AND (AJ|EJ|LJ|MDJ|VJ Precedes NP-ACC*)

AND (NP-ACC* iDoms !CL)

AND (NP-ACC* iDoms !PRO) 